\title{
In Vitro Properties of Potential Probiotic Indigenous Lactic Acid Bacteria Originating from Traditional Pickles
}

\author{
Mehmet Tokatlı, ${ }^{1}$ Gökşen Gülgör, ${ }^{2}$ Simel Bağder Elmacı, ${ }^{3}$ \\ Nurdan Arslankoz İşleyen, ${ }^{4}$ and Filiz Özçelik ${ }^{3}$ \\ ${ }^{1}$ Department of Food Engineering, Faculty of Natural Sciences and Engineering, Gaziosmanpaşa University, 60150 Tokat, Turkey \\ ${ }^{2}$ Department of Food Engineering, Faculty of Agriculture, Uludă̆ University, 16059 Bursa, Turkey \\ ${ }^{3}$ Department of Food Engineering, Faculty of Engineering, Ankara University, 06110 Ankara, Turkey \\ ${ }^{4}$ Yeniçağa Yaşar Çelik Vocational School, Abant İzzet Baysal University, 14650 Bolu, Turkey
}

Correspondence should be addressed to Simel Bağder Elmacı; sbagder@eng.ankara.edu.tr

Received 14 March 2015; Revised 1 May 2015; Accepted 17 May 2015

Academic Editor: Clara G. de los Reyes-Gavilán

Copyright (C) 2015 Mehmet Tokatlı et al. This is an open access article distributed under the Creative Commons Attribution License, which permits unrestricted use, distribution, and reproduction in any medium, provided the original work is properly cited.

\begin{abstract}
The suitable properties of potential probiotic lactic acid bacteria (LAB) strains (preselected among 153 strains on the basis of their potential technological properties) isolated from traditional Cubuk pickles were examined in vitro. For this purpose, these strains (21 Lactobacillus plantarum, 11 Pediococcus ethanolidurans, and 7 Lactobacillus brevis) were tested for the ability to survive at $\mathrm{pH} 2.5$, resistance to bile salts, viability in the presence of pepsin-pancreatin, ability to deconjugate bile salts, cholesterol assimilation, and surface hydrophobicity properties. Most of the properties tested could be assumed to be strain-dependent. However, L. plantarum and $L$. brevis species were found to possess desirable probiotic properties to a greater extent compared to P. ethanolidurans. In contrast to $P$. ethanolidurans strains, the tested L. plantarum and L. brevis strains exhibited bile salt tolerance, albeit to different extent. All tested strains showed less resistance to intestinal conditions than gastric juice environment. Based on the survival under gastrointestinal conditions, 22 of the 39 strains were selected for further characterization. The eight strains having the highest cholesterol assimilation and surface hydrophobicity ratios could be taken as promising probiotic candidates for further in vivo studies, because of the strongest variations found among the tested strains with regard to these properties.
\end{abstract}

\section{Introduction}

There has been an increasing interest in functional foods with health-promoting attributes. Within this context, probiotic foods have received considerable attention in recent years [1]. Probiotics are defined as "live microorganisms that, when administered in adequate amounts, confer a health benefit on the host" [2], as updated by Hill et al. [3]. The beneficial health effects claimed for probiotics are regulation of microbial balance in the gastrointestinal tract, reduction of serum cholesterol levels, alleviation of lactose intolerance symptoms, lowering the risk of colon cancer, enhancement of nutrients bioavailability, prevention or reduction of the prevalence of allergies in susceptible individuals, enhancement of the immune system, and improvement of calcium absorption $[1,4-6]$. As established by the Food and Agriculture Organization and the World Health Organization (FAO/WHO), the main currently used in vitro tests for the study of probiotic strains are resistance to gastric acidity, bile acid resistance, adherence to mucus and/or human epithelial cells and cell lines, antimicrobial activity against potentially pathogenic bacteria, ability to reduce pathogen adhesion to surfaces, and bile salt hydrolase activity [2].

The most commonly used probiotic microorganisms include various species of genera Lactobacillus and Bifidobacterium, as well as some Bacillus, Streptococcus, Pediococcus, and Enterococcus species [7, 8]. In the past, human/animal gastrointestinal tract was considered as the principal source of probiotic strains since those strains of host origin would be better adapted to colonize the human/animal gastrointestinal tract $[9,10]$. Recently, fermented foods, in which probiotics are intended to be used, have drawn attention as source of probiotic organisms [9]. Dairy products have been considered as the best matrices to deliver probiotics $[1,11]$. On 
the other hand, there is a growing interest in the development of non-dairy-based probiotic products due to the drawbacks related to the consumption of dairy products, including lactose intolerance and the unfavourable cholesterol content [4, 8]. Although the use of fermented fruit and vegetable products as raw material for probiotic microorganisms has started to be investigated in several studies $[1,4,9]$, they are still scarce compared with dairy products. In this context, pickle which is a traditional fermented vegetable product could be a promising source of probiotic microorganisms.

The aim of this work was to study some suitable properties of potential probiotic LAB associated with pickles. Thirtynine $\mathrm{LAB}$ isolates originating from naturally fermented pickles were subjected to in vitro analyses to determine their probiotic potential. The properties tested in this study include ability to survive at $\mathrm{pH} 2.5$, resistance to bile salts $(0.3 \%$ oxgall), viability in the presence of pepsin-pancreatin, ability to deconjugate bile salts, cholesterol assimilation, and surface hydrophobicity properties.

\section{Materials and Methods}

2.1. Bacterial Strains and Growth Conditions. A total of 39 indigenous $\mathrm{LAB}$ strains, isolated from pickles produced in Ankara-Çubuk region, were screened for their potential probiotic properties. The tested strains (preselected among 153 LAB strains on the basis of their potential technological properties, including growth ability in MRS Broth, acid production, and tolerance to low $\mathrm{pH}$ ) included $21 \mathrm{~L}$. plantarum, $11 P$. ethanolidurans, and 7 L. brevis strains which were previously identified by molecular methods. The GenBank accession numbers for the 16S rRNA gene sequences of the strains were reported previously [12]. The LAB strains were cultured at $30^{\circ} \mathrm{C}$ for $48 \mathrm{~h}$ in MRS Broth and/or MRS Agar as basal media.

\subsection{Screening for Probiotic Properties}

2.2.1. Resistance to Low pH, Bile Salts, and Simulated Gastric and Intestinal Fluids. To determine the acid tolerance of strains, LAB cells were harvested by centrifugation at $6000 \mathrm{~g}$ for $15 \mathrm{~min}$ after incubation at $30^{\circ} \mathrm{C}$ for $48 \mathrm{~h}$. The collected pellets were suspended in sterile $\mathrm{PBS}$ (phosphate-saline buffer; $9 \mathrm{~g} / \mathrm{L} \mathrm{NaCl}, 9 \mathrm{~g} / \mathrm{L} \mathrm{Na}{ }_{2} \mathrm{HPO}_{4} \cdot 2 \mathrm{H}_{2} \mathrm{O}, 1.5 \mathrm{~g} / \mathrm{L} \mathrm{KH}_{2} \mathrm{PO}_{4}$ ) adjusted to $\mathrm{pH} 2.5$ to the initial volume. The mixture was then incubated at $37^{\circ} \mathrm{C}$ for $4 \mathrm{~h}$. Aliquots of samples were taken at time 0 and after $4 \mathrm{~h}$. These samples were serially diluted in sterile saline solution $(0.85 \% \mathrm{NaCl})$ and the viable cell population was determined by the spread plate method using MRS Agar. The plates were incubated at $37^{\circ} \mathrm{C}$ for $48 \mathrm{~h}$ [13]. The percentage survival of the bacteria was calculated as follows:

$$
\begin{aligned}
\% \text { survival }= & \frac{\log \mathrm{cfu} \text { of viable cells survived }}{\log \mathrm{cfu} \text { of initial viable cells inoculated }} \\
& \times 100 .
\end{aligned}
$$

For the bile salt tolerance assay, MRS Broth containing $0.3 \%(\mathrm{w} / \mathrm{v})$ bile salt (oxgall) was inoculated with active LAB cultures (incubated at $30^{\circ} \mathrm{C}$ for $48 \mathrm{~h}$ ) at an inoculum size of $1 \%$ $(\mathrm{v} / \mathrm{v})$ and incubated at $37^{\circ} \mathrm{C}$ for $4 \mathrm{~h}$. The viable cell population was determined at $0 \mathrm{~h}$ and $4 \mathrm{~h}$ of incubation on MRS Agar plates by the spread plate method. The percentage survival of the bacteria was calculated according to (1) [14].

To test the viability in the presence of pepsin, simulated gastric juice which was prepared by suspending $3 \mathrm{mg} / \mathrm{mL}$ pepsin in sterile saline solution $(0.85 \% \mathrm{NaCl}, \mathrm{w} / \mathrm{v})$ adjusted to $\mathrm{pH} 2.5$ was inoculated with active LAB cultures (incubated at $30^{\circ} \mathrm{C}$ for $48 \mathrm{~h}$ ) at an inoculum size of $1 \%(\mathrm{v} / \mathrm{v})$ and incubated at $37^{\circ} \mathrm{C}$ for $4 \mathrm{~h}$. Simulated intestinal fluid which was prepared by dissolving bile salt $(0.3 \%)$ and pancreatin $(1 \mathrm{mg} / \mathrm{mL})$ in sterile saline solution $(0.85 \% \mathrm{NaCl}, \mathrm{w} / \mathrm{v})$ adjusted to $\mathrm{pH} 8.0$ was used in pancreatin resistance test. This fluid was inoculated with active LAB cultures at an inoculum size of $1 \%(\mathrm{v} / \mathrm{v})$ and incubated at $37^{\circ} \mathrm{C}$ for $6 \mathrm{~h}$. The viable cell population was determined before and after incubation on MRS Agar plates by the spread plate method. The percentage survival of the bacteria was calculated according to $(1)[7,15]$.

2.2.2. Deconjugation of Bile Salts. Deconjugation of bile salt by LAB strains was tested through the plate assay as described by Ahn et al. [16]. $1 \mathrm{mM}$ of sodium taurodeoxycholate hydrate (TDCA), taurocholic acid sodium salt hydrate (TCA), sodium taurolithocholate (TLCA), sodium glycocholate hydrate (GCA), and sodium taurochenodeoxycholate (TCDCA) were added either individually or as a mixture to MRS Agar to prepare Bile salt-MRS Agar plates. The plates were then inoculated with $10 \mu \mathrm{L}$ of active LAB cultures and incubated at $37^{\circ} \mathrm{C}$ for $72 \mathrm{~h}$. Subsequently, diameters of the precipitate halos around colonies were measured.

2.2.3. Cholesterol Assimilation. MRS Broth supplemented with $50 \mu \mathrm{g} / \mathrm{mL}$ water-soluble form of cholesterol (PEG600, Sigma) was inoculated with active LAB cultures at an inoculum size of $1 \%(\mathrm{v} / \mathrm{v})$. After incubation at $37^{\circ} \mathrm{C}$ for $24 \mathrm{~h}$, the culture cells were removed by centrifugation. The collected supernatant and the control, which was the uninoculated sterile broth, were then assayed for their cholesterol content by OPA (o-phthalaldehyde) method as described by Rudel and Morris [17] with slight modifications by Gilliland et al. [18]. Differences in the cholesterol content between the control and the culture test tubes were taken as the assimilated amount of cholesterol.

2.2.4. Surface Hydrophobicity. The adhesion ability of the organisms to hydrocarbons is used as a measure of their hydrophobicity. Briefly, LAB cells were harvested by centrifugation at $6000 \mathrm{~g}$ for $10 \mathrm{~min}$, washed twice in $50 \mathrm{mM} \mathrm{K}_{2} \mathrm{HPO}_{4}$, and then resuspended in the same buffer to obtain an $A_{560 \mathrm{~nm}}$ value of approximately 1.0. Three $\mathrm{mL}$ of bacterial suspension was put in contact with $0.6 \mathrm{~mL}$ of $\mathrm{n}$-hexadecane by vortexing for $2 \mathrm{~min}$. The phases were allowed to separate by decantation at $37^{\circ} \mathrm{C}$ for $1 \mathrm{~h}$. The aqueous phase was carefully removed, and the $A_{560}$ was measured. The decrease in the absorbance of the aqueous phase was taken as a measure of the cell surface hydrophobicity $(\mathrm{H} \%)$, which was calculated with the formula 
TABLE 1: Acid tolerance of LAB strains in PBS ( $\mathrm{pH} 2.5$ ).

\begin{tabular}{|c|c|c|c|c|}
\hline \multirow{2}{*}{ Species } & \multirow{2}{*}{ Strain number } & \multirow{2}{*}{ Initial counts $(\log \mathrm{cfu} / \mathrm{mL})$} & \multicolumn{2}{|c|}{ Survival after $4 \mathrm{~h}$ at $\mathrm{pH} 2.5$} \\
\hline & & & $(\log \mathrm{cfu} / \mathrm{mL})$ & $\%$ \\
\hline \multirow{21}{*}{ L. plantarum } & MF303 & $9.47 \pm 0.04$ & $8.08 \pm 0.16$ & $85^{\mathrm{A}}$ \\
\hline & MF169 & $9.22 \pm 0.05$ & $7.05 \pm 0.17$ & $76^{\mathrm{B}}$ \\
\hline & MF4 & $8.54 \pm 0.07$ & $6.14 \pm 0.07$ & $72^{\mathrm{C}}$ \\
\hline & MF213 & $9.45 \pm 0.05$ & $6.79 \pm 0.10$ & $72^{\mathrm{C}}$ \\
\hline & MF143 & $9.28 \pm 0.01$ & $6.49 \pm 0.01$ & $70^{\mathrm{CD}}$ \\
\hline & MF556 & $9.85 \pm 0.00$ & $6.60 \pm 0.00$ & $67^{\mathrm{DE}}$ \\
\hline & MF376 & $9.94 \pm 0.02$ & $6.28 \pm 0.05$ & $63^{\mathrm{FG}}$ \\
\hline & MF265 & $8.58 \pm 0.06$ & $5.16 \pm 0.11$ & $60^{\mathrm{GH}}$ \\
\hline & MF548 & $9.65 \pm 0.07$ & $5.65 \pm 0.16$ & $59^{\mathrm{H}}$ \\
\hline & MF380 & $9.68 \pm 0.05$ & $5.54 \pm 0.09$ & $57^{\mathrm{H}}$ \\
\hline & MF239 & $9.37 \pm 0.10$ & $4.68 \pm 0.07$ & $50^{\mathrm{I}}$ \\
\hline & MF33 & $9.25 \pm 0.04$ & $4.66 \pm 0.19$ & $50^{\mathrm{I}}$ \\
\hline & MF178 & $8.96 \pm 0.08$ & $3.96 \pm 0.03$ & $44^{\mathrm{J}}$ \\
\hline & MF352 & $9.21 \pm 0.14$ & $3.74 \pm 0.26$ & $41^{\mathrm{JK}}$ \\
\hline & MF377 & $10.04 \pm 0.05$ & $4.06 \pm 0.07$ & $40^{\mathrm{KL}}$ \\
\hline & MF205 & $9.45 \pm 0.11$ & $3.49 \pm 0.02$ & $37^{\mathrm{LM}}$ \\
\hline & MF305 & $9.17 \pm 0.07$ & $3.18 \pm 0.31$ & $35^{\mathrm{MN}}$ \\
\hline & MF150 & $9.23 \pm 0.05$ & $<1.00$ & - \\
\hline & MF219 & $9.01 \pm 0.11$ & $<1.00$ & - \\
\hline & MF357 & $9.83 \pm 0.06$ & $<1.00$ & - \\
\hline & MF513 & $7.75 \pm 0.11$ & $<1.00$ & - \\
\hline \multirow{7}{*}{ L. brevis } & MF493 & $9.37 \pm 0.09$ & $5.99 \pm 0.21$ & $64^{\mathrm{EF}}$ \\
\hline & MF105 & $9.22 \pm 0.08$ & $3.90 \pm 0.12$ & $42^{\mathrm{JK}}$ \\
\hline & MF494 & $9.54 \pm 0.12$ & $3.96 \pm 0.33$ & $42^{\mathrm{JK}}$ \\
\hline & MF343 & $8.80 \pm 0.01$ & $3.45 \pm 0.01$ & $39^{\mathrm{KL}}$ \\
\hline & MF314 & $9.41 \pm 0.12$ & $3.13 \pm 0.02$ & $33^{N}$ \\
\hline & MF158 & $9.44 \pm 0.04$ & $<1.00$ & - \\
\hline & MF354 & $9.10 \pm 0.08$ & $<1.00$ & - \\
\hline \multirow{11}{*}{ P. ethanolidurans } & MF179 & $9.54 \pm 0.15$ & $7.23 \pm 0.06$ & $76^{\mathrm{B}}$ \\
\hline & MF180 & $9.79 \pm 0.01$ & $7.09 \pm 0.04$ & $72^{\mathrm{C}}$ \\
\hline & MF50 & $9.45 \pm 0.04$ & $3.79 \pm 0.05$ & $40^{\mathrm{KL}}$ \\
\hline & MF48 & $9.15 \pm 0.11$ & $<1.00$ & - \\
\hline & MF107 & $9.01 \pm 0.01$ & $<1.00$ & - \\
\hline & MF167 & $9.02 \pm 0.01$ & $<1.00$ & - \\
\hline & MF194 & $9.16 \pm 0.19$ & $<1.00$ & - \\
\hline & MF196 & $9.37 \pm 0.14$ & $<1.00$ & - \\
\hline & MF214 & $9.41 \pm 0.04$ & $<1.00$ & - \\
\hline & MF251 & $9.19 \pm 0.07$ & $<1.00$ & - \\
\hline & MF269 & $9.21 \pm 0.07$ & $<1.00$ & - \\
\hline
\end{tabular}

Values are expressed in mean \pm standard error.

${ }^{A-N}$ Values with different letters within a column indicate significant differences between LAB strains $(p<0.05)$.

$H \%=\left[\left(A_{o}-A\right) / A_{o}\right] * 100$, where $A_{o}$ and $A$ are the absorbance before and after extraction with $\mathrm{n}$-hexadecane [19].

2.2.5. Statistical Analyses. All experiments were conducted in two biological replicates, each with two technical replicates. Experimental data were analysed with one-way ANOVA using the Minitab statistical software, version 14 (Minitab Inc., State College, PA, USA). Statistical differences among means were determined by the Duncan's multiple range tests at the $5 \%$ significance level.

\section{Results and Discussion}

3.1. Resistance to Low pH, Bile Salts, and Simulated Gastric and Intestinal Fluids. Resistance to stomach $\mathrm{pH}$, bile salts, and pancreatic fluid is of great importance in predicting the 
TABLE 2: Bile salt tolerance of LAB strains.

\begin{tabular}{|c|c|c|c|c|}
\hline \multirow[t]{2}{*}{ Species } & \multirow[t]{2}{*}{ Strain number } & \multirow[t]{2}{*}{ Initial counts $(\log \mathrm{cfu} / \mathrm{mL})$} & \multicolumn{2}{|c|}{$\begin{array}{l}\text { Survival after } 4 \mathrm{~h} \text { in the presence } \\
\text { of } 0.3 \%(\mathrm{w} / \mathrm{v}) \text { bile salt (oxgall) }\end{array}$} \\
\hline & & & $(\log \mathrm{cfu} / \mathrm{mL})$ & $\%$ \\
\hline \multirow{17}{*}{ L. plantarum } & MF213 & $9.52 \pm 0.07$ & $9.44 \pm 0.07$ & $99^{\mathrm{A}}$ \\
\hline & MF205 & $8.22 \pm 0.10$ & $7.79 \pm 0.12$ & $95^{\mathrm{B}}$ \\
\hline & MF377 & $8.91 \pm 0.00$ & $8.41 \pm 0.02$ & $94^{\mathrm{B}}$ \\
\hline & MF239 & $7.68 \pm 0.10$ & $6.59 \pm 0.16$ & $86^{\mathrm{C}}$ \\
\hline & MF143 & $8.14 \pm 0.07$ & $6.84 \pm 0.09$ & $84^{\mathrm{CD}}$ \\
\hline & MF305 & $9.32 \pm 0.07$ & $7.51 \pm 0.09$ & $81^{\mathrm{DE}}$ \\
\hline & MF169 & $8.45 \pm 0.16$ & $6.69 \pm 0.30$ & $79^{\mathrm{EF}}$ \\
\hline & MF178 & $9.45 \pm 0.04$ & $7.17 \pm 0.02$ & $76^{\mathrm{F}}$ \\
\hline & MF265 & $9.62 \pm 0.06$ & $7.30 \pm 0.05$ & $76^{\mathrm{F}}$ \\
\hline & MF33 & $9.35 \pm 0.03$ & $6.46 \pm 0.12$ & $69^{\mathrm{G}}$ \\
\hline & MF548 & $9.60 \pm 0.00$ & $6.43 \pm 0.07$ & $67^{\mathrm{G}}$ \\
\hline & MF4 & $9.54 \pm 0.02$ & $5.23 \pm 0.03$ & $55^{\mathrm{H}}$ \\
\hline & MF303 & $9.41 \pm 0.03$ & $5.02 \pm 0.03$ & $53^{\mathrm{H}}$ \\
\hline & MF376 & $9.73 \pm 0.00$ & $4.54 \pm 0.05$ & $47^{\mathrm{I}}$ \\
\hline & MF380 & $9.50 \pm 0.05$ & $4.37 \pm 0.01$ & $46^{\mathrm{I}}$ \\
\hline & MF352 & $8.43 \pm 0.05$ & $3.77 \pm 0.10$ & $45^{\mathrm{I}}$ \\
\hline & MF556 & $9.50 \pm 0.18$ & $4.25 \pm 0.07$ & $45^{\mathrm{I}}$ \\
\hline \multirow{5}{*}{ L. brevis } & MF105 & $9.06 \pm 0.03$ & $8.93 \pm 0.18$ & $99^{\mathrm{A}}$ \\
\hline & MF314 & $9.23 \pm 0.09$ & $9.18 \pm 0.01$ & $99^{\mathrm{A}}$ \\
\hline & MF494 & $9.52 \pm 0.08$ & $9.19 \pm 0.17$ & $97^{\mathrm{AB}}$ \\
\hline & MF493 & $8.96 \pm 0.11$ & $8.50 \pm 0.12$ & $95^{\mathrm{B}}$ \\
\hline & MF343 & $9.36 \pm 0.15$ & $8.81 \pm 0.16$ & $94^{\mathrm{B}}$ \\
\hline \multirow{3}{*}{ P. ethanolidurans } & MF50 & $9.63 \pm 0.01$ & $<1.00$ & - \\
\hline & MF179 & $9.51 \pm 0.04$ & $<1.00$ & - \\
\hline & MF180 & $9.48 \pm 0.00$ & $<1.00$ & - \\
\hline
\end{tabular}

Values are expressed in mean \pm standard error.

${ }^{\mathrm{A}-\mathrm{I}}$ Values with different letters within a column indicate significant differences between LAB strains $(p<0.05)$.

survival and growth of the potential probiotic strains in the gastrointestinal conditions $[7,15]$. Tolerance to gastric acidity ( $\mathrm{pH}$ 2.0-2.5) is considered as a key functional requirement for probiotics, which enables them to survive during passage through the gastrointestinal tract [20]. The viable counts of the $14 \mathrm{LAB}$ strains were found to be below $1 \log \mathrm{cfu} / \mathrm{mL}$ after $4 \mathrm{~h}$ of exposure to $\mathrm{pH} 2.5$, and consequently these strains were not further tested. For the remaining 25 strains belonging to L. plantarum, L. brevis, and P. ethanolidurans, survival at $\mathrm{pH}$ 2.5 for $4 \mathrm{~h}$ was $35-85 \%, 33-64 \%$, and $40-76 \%$, respectively (Table 1). At the species level, the majority of L. plantarum and $L$. brevis strains showed higher resistance to low $\mathrm{pH}$ in comparison with $P$. ethanolidurans strains. The survival ability of lactobacilli at pH 2.5 was also reported by others $[1,21]$. However, variability in acidic response was obtained among the tested strains $(p<0.05)$, indicating that resistance to low $\mathrm{pH}$ is a strain-specific property. Similarly, Jacobsen et al. [22] reported strain-dependent survival of Lactobacillus spp. isolated from Ghanaian fermented maize.

Resistance to bile salts is one of the most important selection criteria for probiotics since the small intestine and colon contain relatively high concentrations of bile salts which are toxic for living cells $[5,23]$. It was reported that the different species of Lactobacillus showed significant variations in relation to their bile salt tolerance [24]. In this study, all studied L. plantarum and L. brevis strains showed varying levels of resistance to bile salts after $4 \mathrm{~h}$ of exposure whereas none of the examined $P$. ethanolidurans strains were able to withstand bile concentration of $0.3 \%$ (Table 2). In particular, 5 selected L. brevis strains were found to be highly tolerant to $0.3 \%$ oxgall exhibiting negligible reduction in viable counts $(<1 \log$ cycle) after $4 \mathrm{~h}$ of incubation (statistical groups labeled with the capital letters A, B, and AB in Table 2). These results were in accordance with the previous studies that showed that the lactobacilli possessed high tolerance to bile salts at $0.3 \%[5,22]$. In contrast, Sukumar and Ghosh [25] reported that Pediococcus spp. which were isolated from an Indian fermented food showed significant bile tolerance. The different survival rates for L. plantarum strains suggest that survival ability in the bile media is strain-dependent, as shown in previous reports $[26,27]$. 
TABLE 3: Survival of LAB strains in simulated gastric and intestinal conditions.

\begin{tabular}{|c|c|c|c|c|c|c|}
\hline \multirow[t]{2}{*}{ Species } & \multirow[t]{2}{*}{ Strain number } & \multirow{2}{*}{$\begin{array}{r}\text { Initial counts } \\
(\log \mathrm{cfu} / \mathrm{mL})\end{array}$} & \multicolumn{2}{|c|}{$\begin{array}{l}\text { Survival after } 4 \mathrm{~h} \text { in } \\
\text { the pepsin-pH } 2.5 \text { solution }\end{array}$} & \multicolumn{2}{|c|}{$\begin{array}{l}\text { Survival after } 6 \mathrm{~h} \text { in the } \\
\text { pancreatin-bile salt solution }(\mathrm{pH} 8.0)\end{array}$} \\
\hline & & & $(\log \mathrm{cfu} / \mathrm{mL})$ & $\%$ & $(\log \mathrm{cfu} / \mathrm{mL})$ & $\%$ \\
\hline \multirow{17}{*}{ L. plantarum } & MF4 & $8.20 \pm 0.02$ & $8.18 \pm 0.20$ & $100^{\mathrm{A}}$ & $<1.00$ & - \\
\hline & MF213 & $8.10 \pm 0.17$ & $8.08 \pm 0.18$ & $100^{\mathrm{A}}$ & $<1.00$ & - \\
\hline & MF376 & $8.32 \pm 0.01$ & $8.30 \pm 0.05$ & $100^{\mathrm{A}}$ & $<1.00$ & - \\
\hline & MF305 & $8.30 \pm 0.15$ & $8.23 \pm 0.03$ & $99^{\mathrm{A}}$ & $<1.00$ & - \\
\hline & MF352 & $8.30 \pm 0.01$ & $6.78 \pm 0.11$ & $82^{\mathrm{B}}$ & $4.11 \pm 0.01$ & $50^{\mathrm{B}}$ \\
\hline & MF548 & $8.25 \pm 0.02$ & $6.78 \pm 0.19$ & $82^{\mathrm{B}}$ & $<1.00$ & - \\
\hline & MF143 & $8.34 \pm 0.11$ & $6.60 \pm 0.03$ & $79^{\mathrm{CD}}$ & $<1.00$ & - \\
\hline & MF239 & $8.26 \pm 0.03$ & $6.54 \pm 0.14$ & $79^{\mathrm{CD}}$ & $<1.00$ & - \\
\hline & MF265 & $8.32 \pm 0.14$ & $6.48 \pm 0.09$ & $78^{\mathrm{DE}}$ & $<1.00$ & - \\
\hline & MF303 & $8.26 \pm 0.03$ & $6.30 \pm 0.02$ & $76^{\mathrm{F}}$ & $3.30 \pm 0.06$ & $40^{\mathrm{C}}$ \\
\hline & MF205 & $8.31 \pm 0.04$ & $6.08 \pm 0.07$ & $73^{\mathrm{G}}$ & $3.30 \pm 0.11$ & $40^{\mathrm{C}}$ \\
\hline & MF380 & $8.22 \pm 0.01$ & $6.00 \pm 0.01$ & $73^{\mathrm{G}}$ & $3.30 \pm 0.07$ & $40^{\mathrm{C}}$ \\
\hline & MF556 & $8.24 \pm 0.09$ & $6.00 \pm 0.16$ & $73^{\mathrm{G}}$ & $3.48 \pm 0.04$ & $42^{\mathrm{C}}$ \\
\hline & MF178 & $8.29 \pm 0.15$ & $5.51 \pm 0.19$ & $66^{\mathrm{H}}$ & $3.48 \pm 0.17$ & $42^{\mathrm{C}}$ \\
\hline & MF377 & $8.30 \pm 0.01$ & $5.48 \pm 0.05$ & $66^{\mathrm{H}}$ & $5.15 \pm 0.02$ & $62^{\mathrm{A}}$ \\
\hline & MF169 & $8.30 \pm 0.03$ & $5.43 \pm 0.08$ & $65^{\mathrm{H}}$ & $5.16 \pm 0.05$ & $62^{\mathrm{A}}$ \\
\hline & MF33 & $8.24 \pm 0.05$ & $4.36 \pm 0.15$ & $53^{\mathrm{I}}$ & $<1.00$ & - \\
\hline \multirow{5}{*}{ L. brevis } & MF314 & $8.34 \pm 0.01$ & $8.28 \pm 0.04$ & $99^{\mathrm{A}}$ & $3.48 \pm 0.16$ & $42^{\mathrm{C}}$ \\
\hline & MF494 & $8.20 \pm 0.17$ & $6.54 \pm 0.07$ & $80^{\mathrm{C}}$ & $5.18 \pm 0.13$ & $63^{\mathrm{A}}$ \\
\hline & MF493 & $8.27 \pm 0.13$ & $6.38 \pm 0.08$ & $77^{\mathrm{EF}}$ & $<1.00$ & - \\
\hline & MF105 & $8.31 \pm 0.02$ & $6.30 \pm 0.03$ & $76^{\mathrm{F}}$ & $5.08 \pm 0.01$ & $61^{\mathrm{A}}$ \\
\hline & MF343 & $8.29 \pm 0.04$ & $<1.00$ & - & $5.07 \pm 0.12$ & $61^{\mathrm{A}}$ \\
\hline \multirow{3}{*}{ P. ethanolidurans } & MF50 & $8.26 \pm 0.06$ & $<1.00$ & - & $<1.00$ & - \\
\hline & MF179 & $8.22 \pm 0.11$ & $<1.00$ & - & $<1.00$ & - \\
\hline & MF180 & $8.34 \pm 0.09$ & $<1.00$ & - & $<1.00$ & - \\
\hline
\end{tabular}

Values are expressed in mean \pm standard error.

${ }^{\mathrm{A}-\mathrm{I}}$ Values with different letters within a column indicate significant differences between LAB strains $(p<0.05)$.

The combined effect of pepsin-pH 2.5 solution and pancreatin-bile salt solution ( $\mathrm{pH} 8.0)$ aims at simulating the gastric juice and the intestine, respectively. The survival rates of LAB in simulated gastric and intestinal conditions are presented in Table 3. Lactobacillus plantarum and L. brevis strains had high survival rates in simulated gastric conditions except for L. brevis MF343, which could not survive after treatment by gastric juice. Although all studied $L$. plantarum and $L$. brevis strains could survive well in the presence of $0.3 \%$ oxgall alone, some of these strains were not able to withstand the simulated intestinal conditions since no viability was observed after $4 \mathrm{~h}$ of exposure. Therefore, it could be suggested that the decrease of viability was due to the pancreatin alone, or in synergy with bile salts. Pediococcus ethanolidurans strains were sensitive to both simulated gastric and intestinal conditions and were then discarded from further analysis. In general, all tested strains showed less resistance to intestinal conditions than gastric juice environment. This could be related to natural adaptation of LAB strains to low $\mathrm{pH}$ conditions since they are of pickle origin. Similarly, Grimoud et al. [28] reported that Lactobacillus strains had higher survival rates under simulated gastric conditions compared to intestinal conditions.

3.2. Deconjugation of Bile Salts. None of the tested strains had the ability to deconjugate bile salts since the cultures did not form precipitate halos around the colonies on Bile saltMRS Agar plates (data not shown). The absence of BSH (bile salt hydrolysis) activity in LAB strains isolated from table olives was also reported in some previous studies [9, 29]. However, it is not straightforward to interpret this result since it is uncertain whether BSH activity is a desirable trait for probiotics because excessive amounts of deconjugated bile salts may be potentially detrimental to the human host $[9,29]$.

3.3. Cholesterol Assimilation. High concentration of cholesterol in the blood streams of humans is generally recognized as a risk factor for coronary heart disease [24, 30]. Consumption of fermented milk products containing certain lactobacilli or bifidobacteria has been asserted to reduce serum cholesterol levels in humans $[16,24,30]$. In this study, 
TABLE 4: Cholesterol assimilation and surface hydrophobicity properties of LAB strains.

\begin{tabular}{|c|c|c|c|}
\hline Species & $\begin{array}{l}\text { Strain } \\
\text { number }\end{array}$ & $\begin{array}{c}\text { Cholesterol } \\
\text { assimilation* }{ }^{*}(\%)\end{array}$ & $\begin{array}{c}\text { Surface } \\
\text { hydrophobicity (\%) }\end{array}$ \\
\hline \multirow{17}{*}{ L. plantarum } & MF4 & $11.72 \pm 0.92^{\mathrm{DEF}}$ & $2.39 \pm 1.57^{\mathrm{M}}$ \\
\hline & MF33 & $43.57 \pm 1.37^{\mathrm{B}}$ & $3.14 \pm 1.16^{\mathrm{LM}}$ \\
\hline & MF143 & $47.69 \pm 0.37^{\mathrm{A}}$ & $39.62 \pm 1.20^{G}$ \\
\hline & MF169 & $44.26 \pm 0.41^{\mathrm{B}}$ & $1.42 \pm 1.42^{\mathrm{M}}$ \\
\hline & MF178 & $12.00 \pm 2.47^{\mathrm{DE}}$ & $32.7 \pm 0.56^{\mathrm{H}}$ \\
\hline & MF205 & $3.85 \pm 0.82^{\mathrm{I}}$ & $3.37 \pm 1.92^{\mathrm{LM}}$ \\
\hline & MF213 & $1.89 \pm 0.87^{\mathrm{I}}$ & $3.18 \pm 2.27^{\mathrm{LM}}$ \\
\hline & MF239 & $9.80 \pm 1.65^{\mathrm{EFG}}$ & $52.02 \pm 0.58^{\mathrm{E}}$ \\
\hline & MF265 & $2.30 \pm 1.10^{\mathrm{I}}$ & $82.41 \pm 0.59^{\mathrm{B}}$ \\
\hline & MF303 & $9.76 \pm 0.78^{\mathrm{EFG}}$ & $0.91 \pm 0.27^{\mathrm{M}}$ \\
\hline & MF305 & $14.06 \pm 0.69^{\mathrm{CD}}$ & $17.72 \pm 0.10^{\mathrm{I}}$ \\
\hline & MF352 & $9.89 \pm 0.46^{\mathrm{EFG}}$ & $8.07 \pm 0.27^{\mathrm{JK}}$ \\
\hline & MF376 & $4.27 \pm 1.05^{\mathrm{HI}}$ & $43.72 \pm 0.49^{\mathrm{F}}$ \\
\hline & MF377 & $8.11 \pm 0.14^{\mathrm{FG}}$ & $2.01 \pm 0.77^{\mathrm{M}}$ \\
\hline & MF380 & $7.33 \pm 0.64^{\mathrm{GH}}$ & $0.66 \pm 0.22^{\mathrm{M}}$ \\
\hline & MF548 & $1.57 \pm 0.37^{\mathrm{I}}$ & $6.25 \pm 0.42^{\mathrm{KL}}$ \\
\hline & MF556 & $48.56 \pm 1.24^{\mathrm{A}}$ & $9.98 \pm 1.60^{J}$ \\
\hline \multirow{5}{*}{ L. brevis } & MF105 & $16.62 \pm 2.88^{\mathrm{C}}$ & $97.96 \pm 0.10^{A}$ \\
\hline & MF314 & $1.79 \pm 0.14^{\mathrm{I}}$ & $8.53 \pm 1.24^{\mathrm{JK}}$ \\
\hline & MF343 & $8.43 \pm 0.82^{\mathrm{EFG}}$ & $0.17 \pm 0.17^{\mathrm{M}}$ \\
\hline & MF493 & $0.83 \pm 0.09^{\mathrm{I}}$ & $62.36 \pm 2.59^{\mathrm{D}}$ \\
\hline & MF494 & $1.61 \pm 0.05^{\mathrm{I}}$ & $67.29 \pm 0.16^{\mathrm{C}}$ \\
\hline
\end{tabular}

Values are expressed in mean \pm standard error.

${ }^{\mathrm{A}-\mathrm{M}}$ Values with different letters within a column indicate significant differences between LAB strains $(p<0.05)$.

* Total cholesterol concentration of the control broth was measured as $45.72 \pm 0.46 \mu \mathrm{g} / \mathrm{mL}$.

the cholesterol assimilation ratios varied depending on the tested strains and ranged from 0.83 to $48.56 \%$. Lactobacillus plantarum strains MF556, MF143, MF169, and MF33 (statistical groups labeled with the capital letters A and B) exhibited significantly higher amounts of cholesterol assimilation compared to other strains tested. As shown in Table 4, these four strains were found to reduce the cholesterol level by $48.56,47.69,44.26$, and $43.57 \%$ in vitro tests, respectively, corresponding to the amount of cholesterol assimilation at ca. $20 \mu \mathrm{g} / \mathrm{mL}$. The wide range of results has been reported on cholesterol assimilation levels of Lactobacillus spp. in previous studies: $13-38 \%$ [31], $14-22 \mu \mathrm{g} / \mathrm{mL}$ [30], and 56-62 $\mu \mathrm{g} / \mathrm{mL}$ [24]. Cholesterol assimilation property appears to show variability across the species and strains. In addition, it is somewhat difficult to compare the present results with other reports since different initial concentration of cholesterol were used. Cholesterol lowering effect of probiotic bacteria has been explained by different proposed mechanisms which include bile salt hydrolase activity, production of compounds that inhibit enzymes such as 3-hydroxy-3-methylglutaryl coenzyme A, and cholesterol assimilation [31]. In the present study, it could be suggested that cholesterol lowering effect of the tested strains was not related to their deconjugation ability of bile salts, in contrast with that found by other authors [16]. On the other hand, Walker and Gilliland [32] found no significant correlation between the ability of L. acidophilus to deconjugate bile acids and the ability to assimilate cholesterol.

3.4. Surface Hydrophobicity. The colonization in intestinal wall is considered as a desirable property of probiotic bacteria [33]. In this context, the adhesion ability to the intestinal epithelium, which is considered to be a prerequisite for colonization, is an important criterion for the selection of probiotic bacteria [34]. The surface properties, like autoaggregation and hydrophobicity, are used as a measurement directly related to ability to adhere to cell monolayers [29, 33]. Some authors found a correlation between hydrophobicity and adhesion ability [35], while some others reported that hydrophobicity values do not correlate with adhesion properties [27]. In the present study, significant differences $(p<0.05)$ in hydrophobicity values were found between LAB strains, even within the same species. At the species level, the hydrophobicity values found ranged from 0.66 to $82.41 \%$ (L. plantarum) and from 0.17 to $97.96 \%$ (L. brevis) (Table 4 ). The results revealed that the greatest hydrophobicity for $n$-hexadecane was observed for L. brevis MF105, L. plantarum MF265, L. brevis MF494, and L. brevis MF493 at 97.96\%, 82.41\%, 67.29\%, and $62.36 \%$, respectively. These four isolates may be considered potential probiotic cultures, from the adhesive point of view. Kumar et al. [36] reported that four Lactobacillus spp., isolated from indigenous pickled vegetables and fermented beverages, exhibited high cell surface hydrophobicity (>60\%).

\section{Conclusion}

Although most of the characteristics tested could be assumed to be strain-dependent, L. plantarum and L. brevis species were found to possess desirable in vitro properties to a greater extent compared to $P$. ethanolidurans. It is difficult to find a strain having all desirable functional properties, and the selection criteria for potential probiotic candidates could therefore be dependent on the purpose of the product. For instance, L. plantarum strains MF556, MF143, MF169, and MF33 exhibited the highest in vitro cholesterol assimilation among the tested strains whereas the maximum hydrophobicity for n-hexadecane was observed for L. brevis MF105, L. plantarum MF265, L. brevis MF494, and L. brevis MF493. Since the strongest variation was found among the tested 22 strains with regard to their cholesterol assimilation and surface hydrophobicity properties, these eight strains could be selected as promising probiotic candidates for further investigation in vivo studies to evaluate their potential health benefits and their application in the food industry.

\section{Conflict of Interests}

The authors declare that they have no conflict of interests. 


\section{Acknowledgment}

This study was supported by the Scientific and Technological Research Council of Turkey (Project no. 108O491).

\section{References}

[1] A. A. Argyri, G. Zoumpopoulou, K.-A. G. Karatzas et al., "Selection of potential probiotic lactic acid bacteria from fermented olives by in vitro tests," Food Microbiology, vol. 33, no. 2, pp. 282291, 2013.

[2] FAO/WHO, Guidelines for the Evaluation of Probiotics in Food, Food and Agriculture Organization (FAO), World Health Organization (WHO), Geneva, Switzerland, 2002.

[3] C. Hill, F. Guarner, G. Reid et al., "The International Scientific Association for Probiotics and Prebiotics consensus statement on the scope and appropriate use of the term probiotic," Nature Reviews Gastroenterology and Hepatology, vol. 11, pp. 506-514, 2014.

[4] K. Y. Yoon, E. E. Woodams, and Y. D. Hang, "Production of probiotic cabbage juice by lactic acid bacteria," Bioresource Technology, vol. 97, no. 12, pp. 1427-1430, 2006.

[5] G. Floros, M. Hatzikamari, E. Litopoulou-Tzanetaki, and N. Tzanetakis, "Probiotic and technological properties of facultatively heterofermentative lactobacilli from Greek traditional cheeses," Food Biotechnology, vol. 26, no. 1, pp. 85-105, 2012.

[6] M. Modzelewska-Kapituła, L. Kłębukowska, K. Kornacki, and W. Łukaszuk, "Characterization of probiotic properties of Lactobacillus strains," Polish Journal of Natural Sciences, vol. 23, no. 2, pp. 366-373, 2008.

[7] H. Musikasang, A. Tani, A. H-kittikun, and S. Maneerat, "Probiotic potential of lactic acid bacteria isolated from chicken gastrointestinal digestive tract," World Journal of Microbiology and Biotechnology, vol. 25, no. 8, pp. 1337-1345, 2009.

[8] R. D. C. S. Ranadheera, S. K. Baines, and M. C. Adams, "Importance of food in probiotic efficacy," Food Research International, vol. 43 , no. 1, pp. 1-7, 2010.

[9] C. Botta, T. Langerholc, A. Cencič, and L. Cocolin, "In vitro selection and characterization of new probiotic candidates from table olive microbiota," PLoS ONE, vol. 9, no. 4, Article ID e94457, 2014.

[10] A. Monteagudo-Mera, L. Rodríguez-Aparicio, J. Rúa et al., "In vitro evaluation of physiological probiotic properties of different lactic acid bacteria strains of dairy and human origin," Journal of Functional Foods, vol. 4, no. 2, pp. 531-541, 2012.

[11] G. Giraffa, N. Chanishvili, and Y. Widyastuti, "Importance of lactobacilli in food and feed biotechnology," Research in Microbiology, vol. 161, no. 6, pp. 480-487, 2010.

[12] S. Bağder Elmacı, M. Tokatlı, D. Dursun, F. Özçelik, and P. Şanlıbaba, "Phenotypic and genotypic identification of lactic acid bacteria isolated from traditional pickles of the Çubuk region in Turkey," Folia Microbiologica, vol. 60, no. 3, pp. 241251, 2015.

[13] P. L. Conway, S. L. Gorbach, and B. R. Goldin, "Survival of lactic acid bacteria in the human stomach and adhesion to intestinal cells," Journal of Dairy Science, vol. 70, no. 1, pp. 1-12, 1987.

[14] H. Yavuzdurmaz, Isolation, characterization, determination of probiotic properties of lactic acid bacteria from human milk [M.S. thesis], Graduate School of Engineering and Sciences of Izmir Institute of Technology, Izmir, Turkey, 2007.
[15] M. Kimura, K. Danno, and H. Yasui, "Immunomodulatory function and probiotic properties of lactic acid bacteria isolated from Mongolian fermented milk," Bioscience and Microflora, vol. 25, no. 4, pp. 147-155, 2006.

[16] Y. T. Ahn, G. B. Kim, K. S. Lim, Y. J. Baek, and H. U. Kim, "Deconjugation of bile salts by Lactobacillus acidophilus isolates," International Dairy Journal, vol. 13, no. 4, pp. 303-311, 2003.

[17] L. L. Rudel and M. D. Morris, "Determination of cholesterol using o-phthalaldehyde," Journal of Lipid Research, vol. 14, no. 3, pp. 364-366, 1973.

[18] S. E. Gilliland, C. R. Nelson, and C. Maxwell, "Assimilation of cholesterol by Lactobacillus acidophilus," Applied and Environmental Microbiology, vol. 49, no. 2, pp. 377-381, 1985.

[19] C. G. Vinderola and J. A. Reinheimer, "Lactic acid starter and probiotic bacteria: a comparative 'in vitro' study of probiotic characteristics and biological barrier resistance," Food Research International, vol. 36, no. 9-10, pp. 895-904, 2003.

[20] A. Bevilacqua, C. Altieri, M. R. Corbo, M. Sinigaglia, and L. I. I. Ouoba, "Characterization of lactic acid bacteria isolated from Italian Bella di Cerignola table olives: selection of potential multifunctional starter cultures," Journal of Food Science, vol. 75, no. 8, pp. M536-M544, 2010.

[21] J. L. Balcázar, D. Vendrell, I. de Blas, I. Ruiz-Zarzuela, J. L. Muzquiz, and O. Girones, "Characterization of probiotic properties of lactic acid bacteria isolated from intestinal microbiota of fish," Aquaculture, vol. 278, no. 1-4, pp. 188-191, 2008.

[22] C. N. Jacobsen, V. R. Nielsen, A. E. Hayford et al., "Screening of probiotic activities of forty-seven strains of Lactobacillus spp. by in vitro techniques and evaluation of the colonization ability of five selected strains in humans," Applied and Environmental Microbiology, vol. 65, no. 11, pp. 4949-4956, 1999.

[23] A. Ahmadova, S. D. Todorov, Y. Choiset et al., "Evaluation of antimicrobial activity, probiotic properties and safety of wild strain Enterococcus faecium AQ71 isolated from Azerbaijani Motal cheese," Food Control, vol. 30, no. 2, pp. 631-641, 2013.

[24] Y. Zheng, Y. Lu, J. Wang, L. Yang, C. Pan, and Y. Huang, "Probiotic properties of Lactobacillus strains isolated from Tibetan kefir grains," PLoS ONE, vol. 8, no. 7, Article ID e69868, 2013.

[25] G. Sukumar and A. R. Ghosh, "Pediococcus spp.-a potential probiotic isolated from Khadi (an Indian fermented food) and identified by $16 \mathrm{~S}$ rDNA sequence analysis," African Journal of Food Science, vol. 4, no. 9, pp. 597-602, 2010.

[26] H. Lee, H. Yoon, Y. Ji et al., "Functional properties of Lactobacillus strains isolated from kimchi," International Journal of Food Microbiology, vol. 145, no. 1, pp. 155-161, 2011.

[27] C. L. Ramos, L. Thorsen, R. F. Schwan, and L. Jespersen, "Strainspecific probiotics properties of Lactobacillus fermentum, Lactobacillus plantarum and Lactobacillus brevis isolates from Brazilian food products," Food Microbiology, vol. 36, no. 1, pp. 22-29, 2013.

[28] J. Grimoud, H. Durand, C. Courtin et al., "In vitro screening of probiotic lactic acid bacteria and prebiotic glucooligosaccharides to select effective synbiotics," Anaerobe, vol. 16, no. 5, pp. 493-500, 2010.

[29] J. Bautista-Gallego, F. N. Arroyo-López, K. Rantsiou, R. Jiménez-Díaz, A. Garrido-Fernández, and L. Cocolin, "Screening of lactic acid bacteria isolated from fermented table olives with probiotic potential," Food Research International, vol. 50, no. 1, pp. 135-142, 2013.

[30] Z. Yu, X. Zhang, S. Li, C. Li, D. Li, and Z. Yang, "Evaluation of probiotic properties of Lactobacillus plantarum strains isolated 
from Chinese sauerkraut," World Journal of Microbiology and Biotechnology, vol. 29, no. 3, pp. 489-498, 2013.

[31] C. Tomaro-Duchesneau, M. L. Jones, D. Shah, P. Jain, S. Saha, and S. Prakash, "Cholesterol assimilation by Lactobacillus probiotic bacteria: an in vitro investigation," BioMed Research International, vol. 2014, Article ID 380316, 9 pages, 2014.

[32] D. K. Walker and S. E. Gilliland, "Relationship among bile tolerance, bile salt deconjugation, and assimilation of cholesterol by Lactobacillus acidophilus," Journal of Dairy Science, vol. 76, no. 4, pp. 956-961, 1993.

[33] C. Iñiguez-Palomares, R. Pérez-Morales, and E. Acedo-Félix, "Evaluation of probiotic properties in Lactobacillus isolated from small intestine of piglets," Revista Latinoamericana de Microbiologia, vol. 49, no. 3-4, pp. 46-54, 2008.

[34] E. Tuomola, R. Crittenden, M. Playne, E. Isolauri, and S. Salminen, "Quality assurance criteria for probiotic bacteria," American Journal of Clinical Nutrition, vol. 73, no. 2, supplement, pp. 393S-398S, 2001.

[35] M. A. Ehrmann, P. Kurzak, J. Bauer, and R. F. Vogel, "Characterization of lactobacilli towards their use as probiotic adjuncts in poultry," Journal of Applied Microbiology, vol. 92, no. 5, pp. 966-975, 2002.

[36] M. Kumar, M. Ghosh, and A. Ganguli, "Mitogenic response and probiotic characteristics of lactic acid bacteria isolated from indigenously pickled vegetables and fermented beverages," World Journal of Microbiology and Biotechnology, vol. 28, no. 2, pp. 703-711, 2012. 

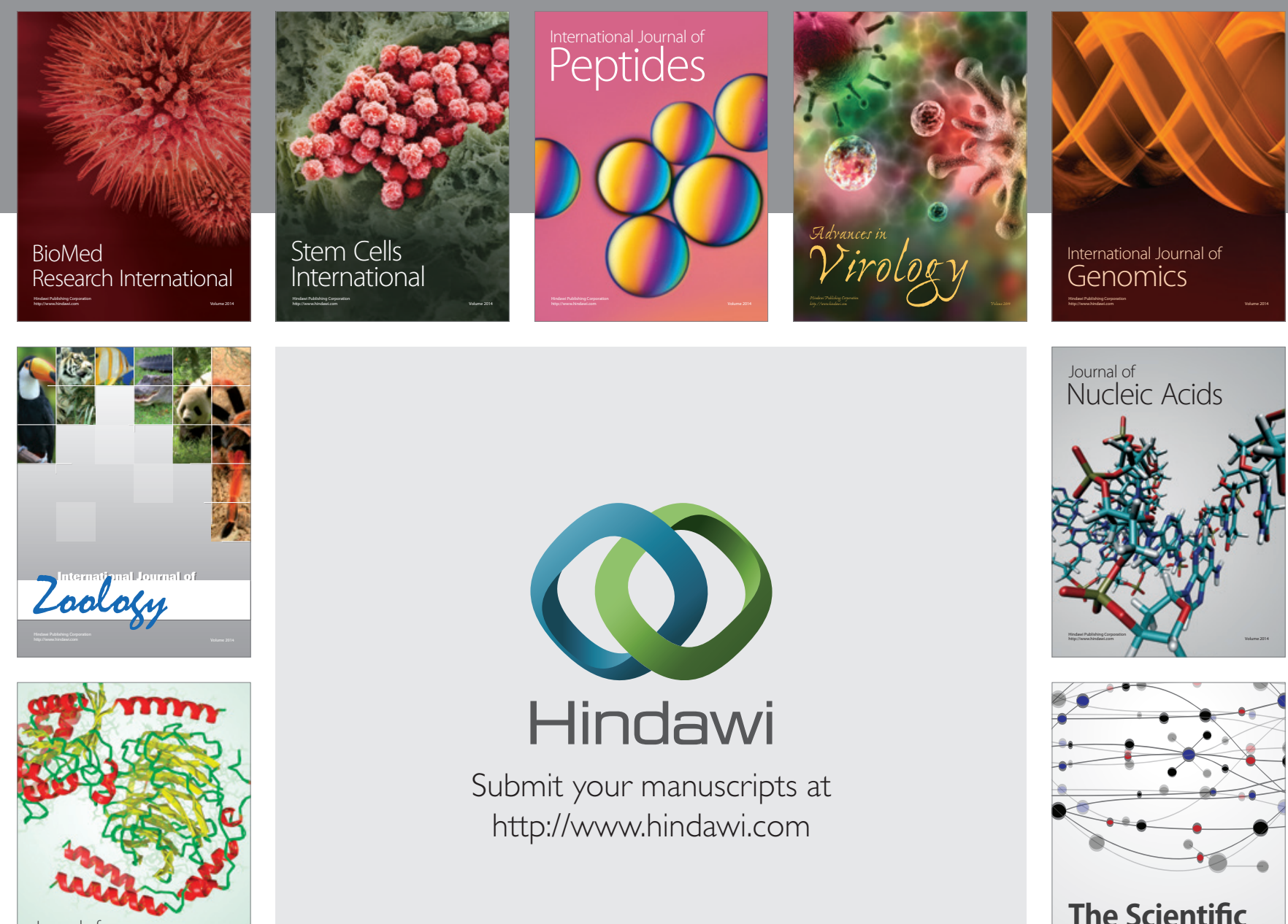

Submit your manuscripts at

http://www.hindawi.com

Journal of
Signal Transduction
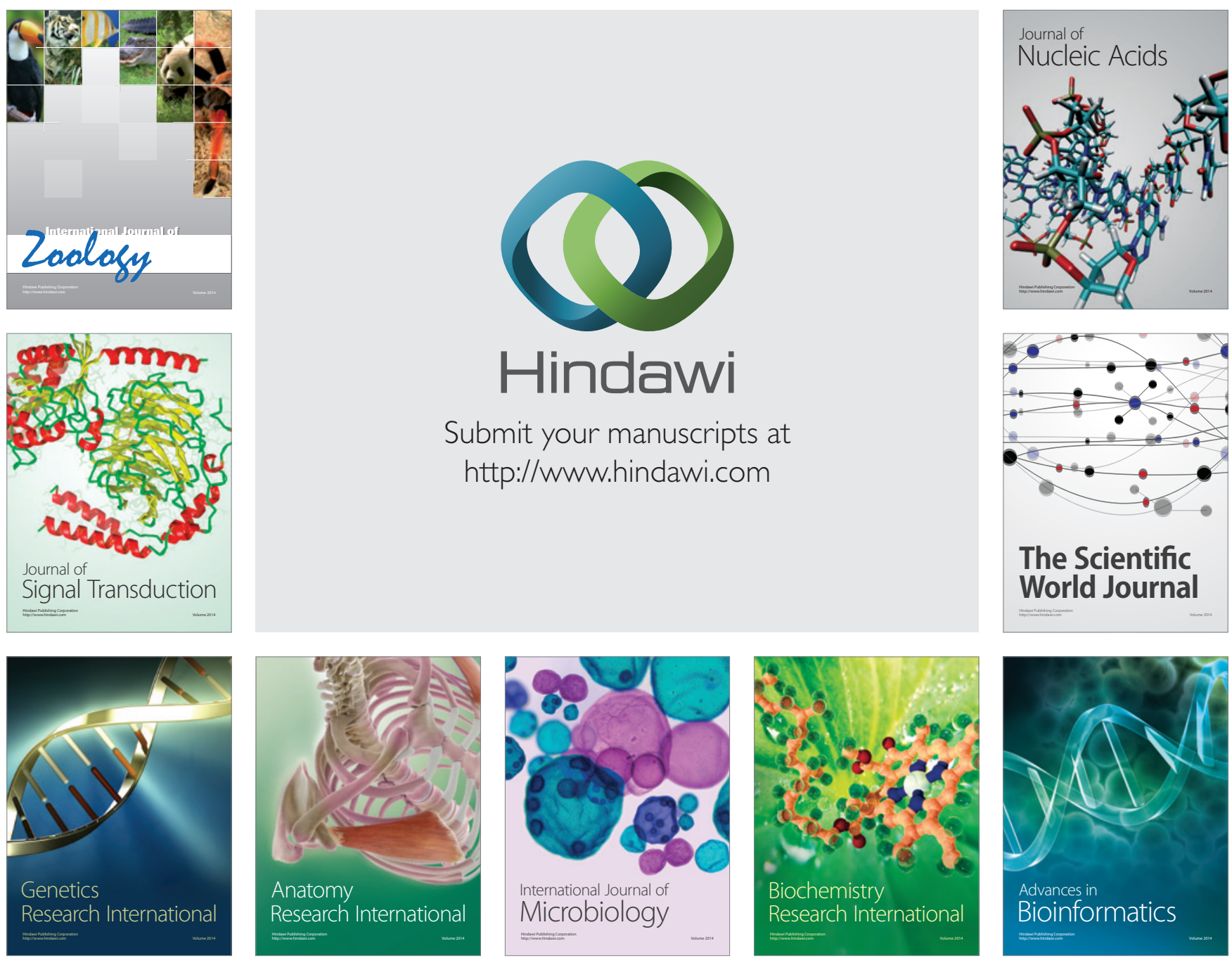

The Scientific World Journal
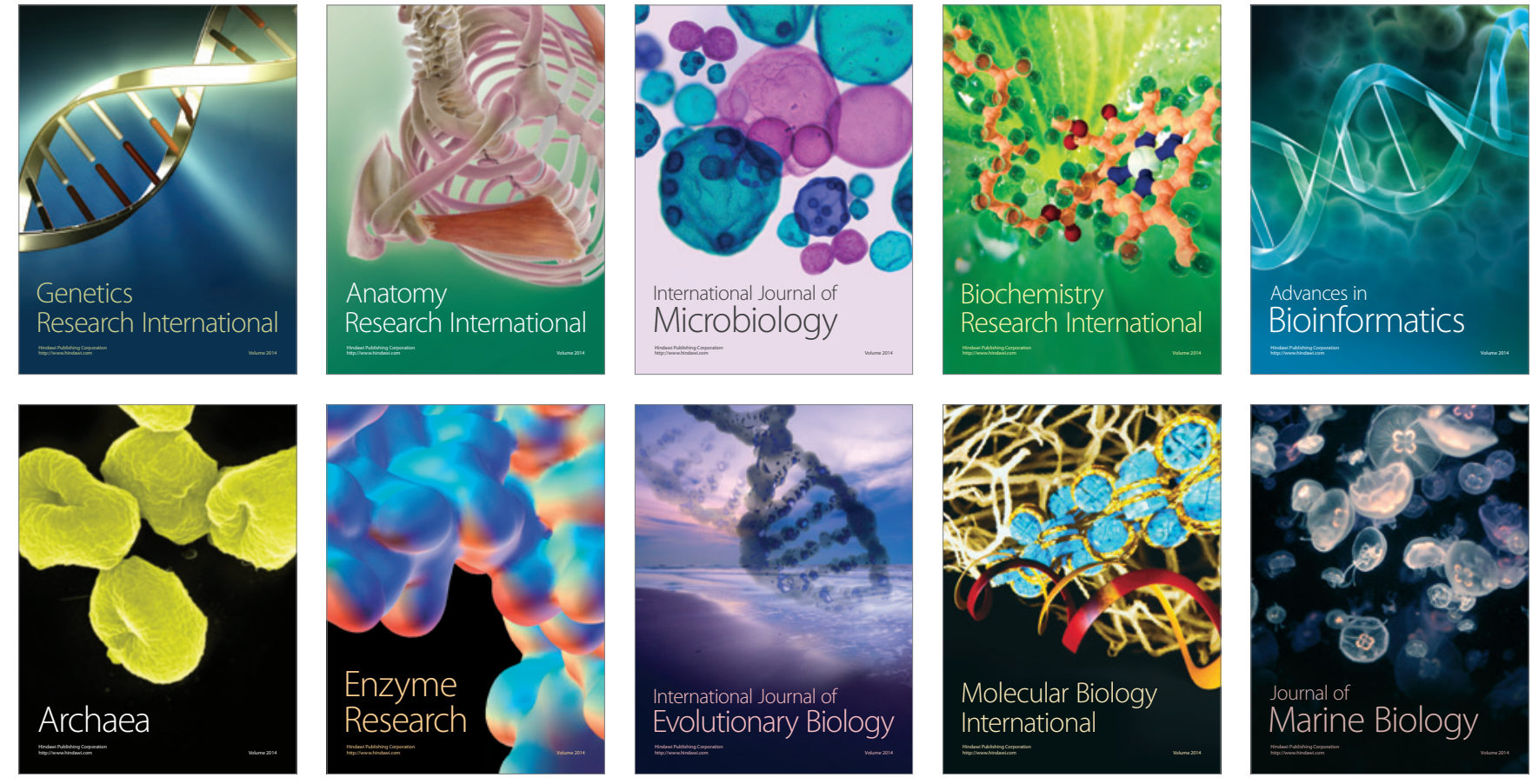